\title{
Impact of the Government Funding Reforms on the Teaching and Learning of Malaysian Public Universities
}

\author{
Abd Rahman Ahmad (Corresponding author) \\ Faculty of Technology Management, Business and Entrepreneurship \\ Universiti Tun Hussein Onn Malaysia, Johor, Malaysia \\ Tel: 607-453-7000 E-mail: arahman@uthm.edu.my \\ Alan Farley \\ School of Accounting and Finance, Faculty of Business and Law \\ Victoria University of Melbourne, Australia \\ E-mail: Alan.Farley@vu.edu.au \\ Moonsamy Naidoo \\ School of Accounting and Finance, Faculty of Business and Law \\ Victoria University of Melbourne, Australia \\ E-mail: Jayce.Naidoo@vu.edu.au
}

Received: April 18, 2012 Accepted: April 26, 2012 Online Published: May 8, 2012

doi:10.5539/hes.v2n2p114

URL: http://dx.doi.org/10.5539/hes.v2n2p114

\begin{abstract}
The Malaysian Government intention to implement the higher education reforms is observable in the implementation of National Higher Education Strategic Plan beyond 2020 in 2007. This plan emphasises on improving the research and teaching in higher education in accordance with the government objectives. Parallel to the introduction of this plan, the government has also initiated the funding reforms which are currently implemented on the public universities. Therefore, this paper will discuss the impact of Malaysian higher education reforms with emphasis on teaching and learning in Malaysian public universities.
\end{abstract}

Keywords: Teaching and learning, Funding reforms, University

\section{Introduction}

As an emerging economy in the region, Malaysian has taken steps to improve its education system to meet global standard. The government's goals to make Malaysia a hub of excellence for higher education by year 2020 is observable through the launching of National Higher Education Strategic Plan beyond 2020 and National Higher Education Action Plan 2007 - 2010 in 2007 (Ministry of Higher Education, 2007a, 2007b). The government's aim is to strengthen the national higher education system by concentrating on sustainable development. Nevertheless, to operate effectively and efficiently most universities and Higher Education Institutions (HEI) require adequate funding sources to improve the quality of teaching and research (Sabry, 2009).Thus, it will become increasingly necessary for Malaysian public universities to diversify their funding and revenue sources from both government and private as proposed by the government funding reforms (Sirat, 2008a). As a result of this reform, public universities are required to generate their own funding in order to supplement the limited and inadequate source of funding from the Federal Government. Moreover, with the introduction of these strategic plans, a comprehensive monitoring, auditing, and reporting systems have been developed to observe how far the government has succeeded in achieving its objectives at the universities level. Indeed, the monitoring will be made periodically at all stages of implementation to ensure the targets are achieved (Ministry of Higher Education, 2007a).

Malaysian public universities are going through a period of significant changes in its attempt to provide high quality of Teaching and Learning (T\&L) to the nation. Given this scenario, it appears that educational institutions should create an intimate link between its goals and accountability to increase the quality of T\&L. This strategic thrust will 
ensure that all students in institutions of higher learning get the benefit from quality learning experiences in line with the needs of individuals, economy and society (Ministry of Higher Education, 2007a). In order to enhance T\&L through Research and Development (R\&D) activities the Ministry of Higher Education (MoHE) has encouraged public universities to increase the number of students at postgraduate level between 18 to 24 per cent in 2010 (Sidhu \& Kaur, 2011). Here, the purpose is to create a research culture community in higher learning institutions.

At this point, this study seeks to address the fundamental research question of whether the changes in Malaysian Federal Government funding have altered the approach in T\&L in Malaysian public universities.

\section{Literature Review}

The need for reform in funding Higher Education Institutions (HEIs) has become a topic of heated debate in government policy discussions in developed and developing countries. These debates have identified a crisis in the structure and management of universities with regard to the quality and accountability of their use of public funding (Cleveland-Innes, 2010; Jongbloed, 2000b; Teixeira \& Koryakina, 2011; Zhao, 2001). Developed countries have shown significant improvement in the execution of their funding system by introducing extensive funding reforms. Developing countries have followed suit and begun to monitor the success and failure of their existing systems of university management and public funding. Indeed, the desire to improve the efficiency and effectiveness of funding HEIs to promote long term benefit to the economic growth have led to the formulation of many policy reforms in developed and developing countries.

An important priority of public policy is to ensure that HEIs contribute to economic growth and social progress as a whole, especially in the context of today's globalised markets and knowledge economy (Macerinskiene \& Vaiksnoraite, 2006). It is crucial for any nation to have a good education system to improve learning outcomes, access to facilities, and efficient use of resources (Newman, Couturier, \& Scurry, 2004).

Managing the higher education sector has become a complex and challenging matter due to globalisation of education markets and increasing demand from the public (Choban, Choban, \& Choban, 2008; Moja, 2007). HEIs face challenges in expanding and developing their operations because governments across the world are now becoming more strict and parsimonious in investing public funds. There is a greater demand for funding owing to growing costs and global competition. But the government resources allocated to public universities are currently insufficient (Salmi \& Hauptman, 2009). Furthermore, Lebeau et al. (2011) add that the world economic crisis has contributed to great pressure on public funded HEIs in most parts of the world. For example, the funding allocation for higher education has declined during the economic down turn in Thailand, Philippines and Malaysia (Postiglione, 2011). Meanwhile, Ko and Osamu (2010) explain that the pressures facing the Japanese higher education come from the global market, funding cuts, social demand and shrinking of the number of students currently. As a consequence, institutions have been directed to search for alternative sources of funds to fill up the funding gap (Jongbloed, 2004; Lepori, Benninghoff, Jongbloed, Salerno, \& Slipersaeter, 2007; Teixeira \& Koryakina, 2011). At the current levels of low government support, funding gap is estimated to become a key factor to a crisis in HEIs.

The universities are usually confronted with problems such as reduction in government funding (Altbach, 2007; Liefner, 2003; Orr, Jaeger, \& Schwarzenberger, 2007; Roger, 1995), stakeholders demanding for greater efficiency (Massy, 2004) and public appeal for better accountability in the management of public funds (Alexander, 2000; Hines, 2000) and finally persistent increase in the cost operating of education (Johnstone, 2004). These challenges have brought positive response from the HEIs, where they are committed to reform and restructure their system to become more competitive. As a result, higher education is facing funding challenges in maintaining the quality of T\&L. As stated before, in public funded systems, financial resources come in form of grant for teaching and research (Beath, Poyago-Theotoky, \& Ulph, 2008). Here, the government funding cuts have the possible impact on the research such as medicine, science and technology which can provide benefit to the public as a whole (Postiglione, 2011).

\subsection{Malaysian Higher Education Background}

The development of education system becomes an important agenda in Malaysia since its independence in 1957. Malaysian has continued to develop national education system in line with the national mission and goal (Kamogawa, 2003; Lee, 2000a; Ministry of Higher Education, 2007a). The government was inspired to transform its national education system where the establishment of the first university in Malaysia known as University Malaya in 1962 became the key national agenda. Today Malaysia has twenty public universities and it is expected that, the Malaysian Government will upgrade more polytechnics and teachers' institution colleges to full class university in the years to come. Continuously, various efforts are being taken by the government in improving the quality of human capital (knowledge, skills and professionalism), including the introduction of Human Capital Policy, National Service Training Program and Vision 2020 in order to meet the demands of first class human capital for the 
purpose of future economic development. As a result of this aspiring vision, the government has formulated major changes on regulations, policies, and plans to foster the development of education system in Malaysia. In many ways these regulatory procedures has not only enabled the government to control HEIs behaviour to meet its targeted objectives as planned but has also allowed the government to tighten control over the advancement of higher education system (Lee, 2000b).

\subsection{The Structure of Higher Education System in Malaysia}

Higher education in Malaysia employs a dualistic system comprising both public and private HEIs in order to provide education services to local and international students. Both institutions of higher learning offer courses leading to the award of certificate, diploma, first degree and higher degree. The distributions of Malaysian HEIs are illustrated in Table 1 below.

Insert Table 1 about here.

In total there are about 107 public HEIs and 515 private HEIs owned by private sectors in 2010. However, private HEIs take a bigger share of the higher education market in Malaysia and rely on government funding whilst the private HEIs depend on individual resources, and hence, funding reforms proposed by the Malaysian Federal Government are not applicable on them. Out of the total number of public institutions in Malaysia, twenty of them are public universities, and 87 are non- university institutions. The non-university institutions of public HEIs include Polytechnics, Community Colleges, Public Colleges, and Teacher Education Institutions. As for private sector, there are about 27 universities and 488 colleges are classified as non-university status within that year.

\subsection{Malaysian Higher Education Reforms}

The committees study, review and make recommendations on the development and direction of higher education in Malaysia where they propose that higher education in Malaysia is a strategic investment and the Federal Government should continue to provide financial support by increasing the total funding in order to improve the quality and quantity of Malaysian human capital (Ministry of Higher Education, 2006). In addition, the committees highlighted some key areas of the recommendation which focused on increasing opportunities for Malaysians to participate in national higher education and ultimately enhance the quality of T\&L. Previous research has indicated that funding systems is one of the most important tools for policy change in higher education institutions (Kettunen, 2008; Rolfe, 2003; Strehl, Reisinger, \& Kalatschan, 2007a). According to Johnstone (1998), funding reform can intervene in situations such as: (1) expansion and diversification; (2) fiscal pressure; (3) market orientation; (4) demand for greater accountability; and (5) demand for greater quality and efficiency. Hence, improved funding system can stimulate strategic activities including T\&L. Funding reform according to Schiller \& Liefner (2006) encompasses among other; government budget cuts, performance-based funding mechanism and diversification of the funding base. Previous research studies pointed that funding shift has an intended and unintended effects on the HEIs core function on teaching and research (Tammi, 2009).

In the case of Malaysia, prior to the reforms, funding and resource allocation mechanisms in Malaysia still depended on the traditional approach of negotiation between public universities and the Ministry of Higher Education. A consulting body published a study in 2004 exploring the feasibility of introducing a transparent funding formula, found and further suggested that performance-based funding model could save Ministry of Higher Education 10 to 30 per cent of the operating budget of the public universities resource (World Bank/EPU, 2007). This model creates channels of finance flowing to HEIs which are transparent and accountable in the usage of public funds and therefore ensures that the public receives better value for the money spent.

As the Prime Minister announced in the Tenth Malaysian Plan, 2011-2015, the government has also initiated SETARA - a system of rating Malaysian universities and university colleges. The system consists of two components; the fixed components that include salary of faculties' members and cost of utilities and the variable components which embraced intellectual development in R\&D and student co-curricular activities based on the SETARA performance rating (Economic Planning Unit, 2010a). Also, it has generally been noted that students' enrolments, quality of T\&L, publications, R\&D, patents, and licences are some good indicators of performance as criteria in deciding funding allocations (Jongbloed \& Vossensteyn, 2001). They further argued that the successful funding methods currently in use in HEIs have a strong affinity with market-oriented mechanisms with techniques to measure output, productivity, and performance indicators.

In the context of HEIs, the most recent type of performance indicators used to measure institutional performance in teaching and research are set out according to budgeting and resource allocation. Kivistö (2005) adds that the government has to utilise indicators that are not only relevant for measuring institutional performance but responsive to broader social and economic factors in a particular context. Thus, performance indicators can become a 
cornerstone for measuring institutional effectiveness and promoting quality of output (Chen, Wang, \& Yang, 2009). Tracking the performance of higher education help improve the business process utilised in institutions (Serdar, 2010).

Insert Table 2 about here.

With the National Higher Education Plan beyond 2020, the Malaysian Federal Government has also formulated a policy where HEIs are given greater responsibility in sourcing and pursuing alternative funding. Almost all countries today rely on large scale government funding to improve the quality of higher education (Roger, 1995). In Malaysia for example, education funding is allocated according to the annual budget and in the recent 2012 Budget proposal, an amount of RM50.2 billion has been granted to the education sector. (Malaysian Treasury, 2011). Ahmad Nurulazam et al. (2008) in their study observed the impact of changes in the policy and they found that HEIs is expected to generate fund from different sources so that the academic quality in teaching, development and equity of higher education can be developed without relying solely on government funding. This strategy is deemed to create strategic linkages that help institutions to diversify their activities and commercialise their research which will diversify their source of fund. Sato (2007) finds that Malaysian public universities are now moving away from government budget to self funding and this has led to the delivery of better services and ability to generate more income. The statement from Sato is further confirmed when the government announced on the reduction of universities funding in the Tenth Malaysian Plan (Economic Planning Unit, 2010a).

Furthermore, the government has introduced a system which categorises Malaysian public universities according to their area of specialisation and therefore fund will be allocated based on the specialisation of the university and the extent of its operations. Currently, there are about twenty public universities in the country operating on funding support and subsidies from the Malaysian Government. They are now categorised into three main groups; Research University (RU), Comprehensive University (CU) and Focused University (FU). Research Universities (RUs) have been allocated additional funding of RM50 million every year to support their R\&D activities while Comprehensive Universities (CUs) and Focused Universities (FUs) which offer structured courses for all levels of tertiary education are given funds according to their needs (Ministry of Higher Education, 2007a).

\section{Methodology}

The method employed for data collection is based on the survey questionnaire and focus group interview. The survey questionnaires were distributed to all selected samples in the Malaysian public universities. The questions in this survey were organised in two sections; the first section dealt with questions related to demographical information, while the second section included questions on changes in government funding that were related to T\&L.

In this study, criteria used in the selection of samples in the population are carefully designed to include the officers with important occupational positions in the university top management in order to increase the quality of information retrieved. Personnel who are not dealing with university finances may not have knowledge of the planning and implementation of government funding changes in public universities; thus, the respondents selected are only those who have more than fifteen years of relevant experience. The selected respondents in those positions are deemed to have extensive management experience and expert knowledge related to changes in university policies. Therefore, this questionnaire survey was distributed to all twenty public universities in Malaysia, incorporating the Vice Chancellors, Deputy Vice Chancellors, Deans, Directors of Strategic Planning or equivalent, and Heads of Bursar Office or equivalent.

Table 3 presents the statistical test used in this study. It includes the parametric one-sample $\mathrm{T}$ test and one-sample non-parametric and Wilcoxon signed ranks test. One sample Wilcoxon signed rank test is a non-parametric alternative method of one sample t-test, which is used in this study to test whether a sample median of the measurement is equal to a specified value. Where the truth average value is greater than four (neutral) when tested, this indicates the respondents' agreement or disagreement with each statement on the impact of changes in government funding in Malaysia public universities on the approach to T\&L that are based on seven-point scale ranging from 1=strongly disagree to $7=$ strongly agree.

Insert Table 3 about here.

In order to increase data from the quantitative analysis, this research moved one step further by adopting focus group interviews for the purpose of triangulation; this serves to provide credibility through using both qualitative and quantitative analysis (McLafferty, 2004). Thus, data gathered from the survey than was then confirmed and enhanced by results from the focus group interviews. Participants in the focus group interviews had the experience and knowledge needed to contribute additional information to enrich the results, drawing from the Dean, Director of Strategic Planning Office or equivalent, Head of Research and Management Centre or equivalent and Head of 
Bursar Office or equivalent. These interviews were well planned using the practice framework for focus group interviews suggested by Krueger and Casey (2009). Table 4 below shows the classification of Malaysian public universities that are based on three main categories: (1) Research University; (2) Comprehensive University; and (3) Focused University.

Insert Table 4 about here.

\section{Finding}

As samples selected in this study are those who are engaged with the university top management, the researcher has to increase efforts to obtain prompt feedback from them either by direct visits, mails, e-mails or regular follow up as ways to get good responses. From the total of 338 questionnaires distributed to all Malaysian public universities, 120 usable questionnaires are returned and the descriptive analyses are presented as follows.

\subsection{Demographic Analysis}

Table 5 reports on the distribution of total respondents according to the pre-determined demographic profile such as the category of universities and designated position.

Insert Table 5 about here.

As indicated in Table 5, 43.3 per cent of the respondents in this study are from FUs; followed by 34.1 per cent from the RUs and 8.30 per cent is from Apex University. The 22.5 per cent of the respondents are from CUs. In terms of the respondents' position in the universities, most of the selected respondents are Deans (67.5\%) and Deputy Vice Chancellors/Deputy Rectors (16.7\%). Approximately, 7.5 per cent of the respondents are Heads of Bursar Office or equivalent and only 1.7 per cent or 2 respondents are Vice Chancellors/Rectors.

\subsection{Results of One Sample Wilcoxon Signed Rank Test and One Sample T-Test}

Results from the one sample Wilcoxon signed rank test and one sample T-test is presented in table below. Insert Table 6 about here.

The results of one sample Wilcoxon signed rank test and one sample T-test shows that the respondents in this study have agreed on the impact of changes on government funding system and the fact that the changes have altered the approach on T\&L in Malaysian public universities. Results shows that there were statistically significant difference at the $\mathrm{p}<0.0005$ level. The mean scores from one sample T-test presented in table above demonstrated the value of above four for all items. The majority of the respondents were agreed that changes in Malaysian government funding have altered the approach to T\&L.

\subsection{Results from Focus Group Interviews}

In this sub-section analysis of data from focus group interviews concerning the effects of funding changes on T\&L i.e. teaching and learning is discussed. Evidence indicates that participants from University A, B, C and D have the same impressions about government efforts towards maximum utilisation of available funding. They all felt that apart from research the government is trying to put greater focus on increasing the quality of T\&L according to university strengths. However, due to funding constraints, public universities are required to be more creative to ensure that the T\&L quality remains their main priority.

However, participants in this study pointed out that at these stage universities were facing a problem in recruiting new academic staff due to some budget constraints. They pointed out that this problem may affect their strategic planning in T\&L. In the short run, universities were using their own creativity like multi-tasking and appointing contract staff for a short period, to overcome this problem. A participant at University D highlighted spoke about the impact of funding changes on T\&L and their strategies to overcome obstacles to good teaching and will not compromise on this issue and things that contribute directly to T\&L. Evidence indicates that some of the universities are applying multitasking approaches to overcome the shortage of academic staff. This is to ensure that even at the most difficult times T\&L activities are not affected. In the meantime, participants at University B pointed out that they were using the facilities of R\&D on a shared basis with T\&L activities to maximise their resources but still felt the shortage of skilled academic staff.

While there are some other issues detracting from good T\&L, it can be concluded that these are not the result of the funding changes. On the contrary, evidence indicates that universities are working in line with GOs despite the funding constraints and the participants were agreed that changes in funding would not affect the quality of T\&L.

In this study, participants were agreed that such performance measurement required by the government led to better communication. They were enthusiastic about the systematic manner of performance measurement ushered in by KPIs that set clear goals and gave measurable outcomes. The government has also indicated strong interest in monitoring and reporting T\&L performances at public universities. As mentioned before, some of the KPIs under 
Critical Agenda Projects (CAPs) are used to monitor the T\&L. At the university level, a department monitors the performance of T\&L activities and the KPIs were audited and monitored by the government on a regular basis. All the information reported is for the use of the government to make decisions and create strategic plans to improve the quality of T\&L by providing additional resources to the public universities if needed.

In addition evidence regarding on perception about impact of funding changes on T\&L indicated that participants at University A and C replied that they were happy with the changes. However, participants at University B felt that it had positive as well as negative implications for T\&L at their university. Finally, participants at University D said that they were not happy with these changes. The reason of the perception due to that funding change cause teaching university does not have enough funds.

\section{Discussion}

This study conforms previous research that changes on funding mechanisms affect the composition of T\&L where the universities are more accountable with public expenses in order to improve the quality (Liefner, 2003; Schiller \& Liefner, 2006). There is a greater concern that the public universities would never be neglected in the quality of T\&L even in the difficult position. The results are constructive since the Federal Government vision is to make Malaysia for higher education hub in the Southeast Asia region (Economic Planning Unit, 2010; Knight \& Sirat, 2011). Therefore, the public universities should plays significance role in performing educational policy that can be seen by the increasing the number of local and international students. The results of this study is very useful to the government because it is a signal that all the effort outline in the strategic plans are given full attention by the public universities, especially during the limited sources of funds.

Interestingly, the result from the survey questionnaire revealed that changes in government funding systems have not affected the number of undergraduate, postgraduate and international students' enrolment and number of undergraduate and postgraduate degrees offered at the Malaysian public universities. These results are consistent with the Federal Government vision to establish Malaysia as a higher education hub in the Southeast Asia region (Economic Planning Unit, 2010; Knight \& Sirat, 2011). Therefore, the public universities should play significant role in performing educational policy that can be seen by the increasing the number of local and international students.

Despite the above improvement in T\&L activities, the public universities in Malaysia also facing problem due to shortage of academic staff during this funding reforms. The interview data revealed that the universities are using their creativity to overcome this problem in order to ensure the quality of T\&L at the standard level. Supringsly, the findings suggest that the universities are not going to use these reasons when confronted with this issue. The results are also consistent with other studies and suggest that the universities should implement cost sharing strategy in order to overcome the funding cuts (Mohrman, Ma, \& Baker, 2008; Ogbogu, 2011). In dealing with these challenges, the public universities should focus on innovation in designing the curriculum. In addition, the universities should design a proactive approach to attract industrial experienced people to join the university workforce. However, to implement this policy, the government and university should consider several packages which include attractive salaries and incentive for them.

The Malaysian government seeks to develop strategies and plans to ensure that HEIs in Malaysia are encouraged to undertake changes and achieve excellence to face the competition posed by the global education market. The objective of these plans is to ensure that Malaysian universities achieve world-class status and operate as a hub for higher education in the Southeast Asia region (Ministry of Higher Education, 2007a). The introduction of funding reforms as shown in this study is expected to have a positive impact on the universities T\&L activities. The Malaysian public universities should be creative in managing the limited government funds to ensure all activities related to T\&L are given due priority.

Indeed, in order to develop a competitive advantage in the challenging global environment, universities need to develop strong strategic plans that are aligned closely with the government vision. This is because changes in educational systems have led many countries to restructure their resources to finance higher education. As a result, the Malaysian public universities need to transform themselves in order to meet the challenges presented by these policies by realigning their organisations with the environment, redesigning themselves to achieve new goals, redefining staff roles and responsibilities, and reengineering their organisational processes. In response to that, HEIs need to implement strategies that are congruent with the government objectives. Moreover, a good monitoring system can help enhance the government's capacity to assess efficient management of resources, assist in eliminating redundancy of programs and projects and ensure that the nation's resources are allocated proportionately to its priorities. 


\section{Conclusion}

This research concludes that the government funding reforms have altered the approach to T\&L in Malaysian public universities. The higher education environment has changed public universities to develop strategies that are focussed in achieving the government objectives.

HEIs need to shift the resource allocation mechanism with targeted to excel in both teaching and research. The use of performance based funding that will be implemented to all Malaysian public universities will stimulate Malaysian universities to be more competitive. Ultimately, the most important question is to address the issues maintaining the nature and scope of HEIs in teaching and research that will contribute to economic growth. Therefore, funding reform proposed by the government should take into account the contribution of higher education to society at large. Based on that argument, the following recommendations should be considered by the Malaysian Government as a way to implement funding reforms and strategic plans:

- Determine the funding allocation based on the university strengths. Attention should be given to the new universities which are in dire needs for adequate funds in order to meet the minimum requirement for T\&L;

- Efforts should be directed towards improving the quality of T\&L in order to attract more international students to study at public universities. This includes increasing the capacity of academic staff in teaching and research; and

- Improve the monitoring system (auditing, reporting and controlling) in order to ensure that public universities implement the strategic plans in accordance with the government objectives as stated in the National Higher Education Strategic Plan Beyond 2020.

\section{References}

Ahmad Nurulazam Md Zain, Aida Suraya Md Yunus, Ibrahim Che Omar, Morshidi Sirat, Munir Shuib, Rosni Bakar, \& Sukran Abdul Rahman. (2008). Sistem pendidikan tinggi dan model universiti untuk Malaysia: Pengisian (Vol. 12): National Higher Education Research Institute (NHERI).

Alexander, F. (2000). The changing face of accountability: Monitoring and assessing institutional performance in higher education. Journal of Higher Education, 411-431. http://dx.doi.org/10.2307/2649146

Altbach, P. (2007). The complex roles of universities in the period of globalization.

Bonaccorsi, A., \& Daraio, C. (2007). Universities and strategic knowledge creation: Speclialization and performance: Edward Elger Publishing Limited.

Cave, M., Kogan, M., \& Hanney, S. (1989). Performance measurement in higher education. Public Money \& Management, 9(1), 11-16.

Chen, S., Wang, H., \& Yang, K. (2009). Establishment and application of performance measure indicators for universities. The TQM Magazine, 21(3), 220-235. http://dx.doi.org/10.1108/17542730910953004

Choban, M. C., Choban, G. M., \& Choban, D. (2008). Strategic planning and decision making in higher education: What gets attention and what doesn't. Assessment Update, 20(2), 1-14.

Cleveland-Innes, M. (2010). New directions for higher education: Challenges, opportunities, and outcomes (pp. 133-147). Berlin, Heidelberg: Springer Berlin Heidelberg.

Economic Planning Unit. (2010). Rancangan Malaysia Kesepuluh (RMKe-10). Putrajaya: [Online] Available: http://www.epu.gov.my/rmkesepuluh.

Economic Planning Unit. (2010a). Rancangan Malaysia Kesepuluh (RMKe-10). [Online] Available: Economic Planning Unit http://www.epu.gov.my/rmkesepuluh (August 25, 2010)

Guthrie, J., \& Neumann, R. (2007). Economic and non-financial performance indicators in universities. Public Management Review, 9(2), 231-252. http://dx.doi.org/10.1080/14719030701340390

Hines, E. (2000). The governance of higher education. Higher Education, 15, 105-155.

Johnstone, D. (2004). The economics and politics of cost sharing in higher education: comparative perspectives* 1. Economics of Education Review', 23(4), 403-410. http://dx.doi.org/10.1016/j.econedurev.2003.09.004

Jongbloed, B. (2000b). The funding of higher education in developing countries. Management \& Policy in Higher Education, 32, 13-42.

Jongbloed, B. (2004). Funding higher education: options, trade-offs and dilemmas. Fulbright Brainstorms, 24-25. 
Jongbloed, B., \& Vossensteyn, H. (2001). Keeping up performances: An international survey of performance-based funding in higher education. Journal of higher education policy \& management, 23(2), 127-145. http://dx.doi.org/10.1080/13600800120088625

Kamogawa, A. (2003). Higher education reform: Challenges towards a knowledge society in Malaysia. African \& Asian Studies, 2(4), 545-563. http://dx.doi.org/10.1163/156920903773004059

Kettunen, J. (2008). A conceptual framework to help evaluate the quality of institutional performance. Quality Assurance in Education, 16(4), 322-332. http://dx.doi.org/10.1108/09684880810906472

Knight, J., \& Sirat, M. (2011). The complexities and challenges of regional education hubs: Focus on Malaysia. Journal of Higher Education, 62(5), 593-606.

Ko, N., \& Osamu, A. (2010). Higher education for sustainable development in Japan: Policy and progress. International Journal of Sustainability in Higher Education, 11(2), 120-129. doi: 10.1108/14676371011031847

Krueger, R. A., \& Casey, M. A. (2009). Focus groups : A practical guide for applied research (4th ed.). Thousand Oaks: Sage Publications.

Lebeau, Y., Stumpf, R., Brown, R., Lucchesi, M. A. S., \& Kwiek, M. (2011). Who shall pay for the public good? Comparative trends in the funding crisis of public higher education. Compare: A Journal of Comparative and International Education, 42(1), 137-157. doi: 10.1080/03057925.2012.635418

Lee, M. (2000a). The impacts of globalization on education in Malaysia. Globalization and education: Integration and contestation across cultures, 315-332.

Lee, M. (2000b). Expanding the state role in Malaysian higher education. Paper presented at the International Higher Education.

Lepori, B., Benninghoff, M., Jongbloed, B., Salerno, C., \& Slipersaeter, S. (2007). 3. Changing models and patterns of higher education funding: some empirical evidence. Universities and strategic knowledge creation: specialization and performance in Europe, 85.

Liefner, I. (2003). Funding, resource allocation, and performance in higher education systems. Journal of Higher Education 46, 469-489. http://dx.doi.org/10.1023/A:1027381906977

Macerinskiene, I., \& Vaiksnoraite, B. (2006). The role of higher education to economic development. [Online] Available: http://www.leidykla.vu.lt/fileadmin/Vadyba/11/Irena_Macerinskiene_Birute_Vaiksnoraite.pdf (February 9, 2010)

Malaysian Treasury. (2011). The 2012 Budget Speech. Retrieved 30 October 2011, from Malaysian Treasury website. [Online] Available:http://www.treasury.gov.my/pdf/bajet/ub12.pdf

Massy, W. (2004). Markets in higher education: Do they promote internal efficiency? Higher Education Dynamics 6, 13-36. http://dx.doi.org/10.1007/1-4020-2835-0_2

McLafferty, I. (2004). Focus group interviews as a data collecting strategy. Journal of Advanced Nursing, 48(2), 187-194.http://dx.doi.org/10.1111/j.1365-2648.2004.03186.x. PMid:15369499

Ministry of Higher Education. (2006). The report by the committee to study, review and make recommendations concerning the development and direction of higher education in Malaysia: Ministry of Higher Education.

Ministry of Higher Education. (2007a). Pelan strategik pengajian tinggi negara melangkau tahun 2020. Putrajaya.

Ministry of Higher Education. (2007b). National higher education action plan 2007-2010. In M. o. H. Education (Ed.). Putrajaya.

Ministry of Higher Education. (2010). Perangkaan pengajian tinggi Malaysia 2010. In B. P. d. Penyelidikan (Ed.). Kuala Lumpur: Bahagian Perancangan dan Penyelidikan, Kementerian Pengajian Tinggi Malaysia.

Mohrman, K., Ma, W., \& Baker, D. (2008). The research university in transition: the emerging global model. Higher Education Policy, 21(1), 5-27. http://dx.doi.org/10.1057/palgrave.hep.8300175

Moja, T. (2007). Institutional challenges and implications for HEIS: transformation, mission and vision for the 21st century.

Neumann, R. T., \& Guthrie, J. (2006). Performance Indicators in Australian Universities: Establishment, Development and Issues. Presented to the EIASM 2nd Workshop on the Process of Reform of University Systems, 4-6 May 2006, Venice, Italy. 
Newman, F., Couturier, L., \& Scurry, J. (2004). The future of higher education : rhetoric, reality, and the risks of the market (1st ed.). San Francisco: Jossey-Bass.

Ogbogu, C. O. (2011). Modes of funding Nigerian universities and the implications on performance. Journal of International Education Research, 7(4).

Orr, D., Jaeger, M., \& Schwarzenberger, A. (2007). Performance-based funding as an instrument of competition in German higher education. Journal of Higher Education Policy \& Management, 29(1), 3-23. http://dx.doi.org/10.1080/13600800600980072

Postiglione, G. A. (2011). Global recession and higher education in eastern Asia: China, Mongolia and Vietnam. Higher Education, 62(6), 789-814. http://dx.doi.org/10.1007/s10734-011-9420-4

Roger, K. (1995). What is higher education for? Strategic dilemmas for the twenty-first century university. Quality Assurance in Education, 3, 14-20. http://dx.doi.org/10.1007/s10734-011-9420-4

Rolfe, H. (2003). University strategy in an age of uncertainty: The effect of higher education funding on old and new universities. Higher Education Quarterly, 57(1), 24. http://dx.doi.org/10.1111/1468-2273.00233

Sabry, M. (2009). Funding policy and higher education in Arab Countries. Comparative \& International Higher Education, 1.

Salmi, J., \& Hauptman, A. (2009). Resource allocation mechanisms in tertirary education: A typology and an assessment.

Sato, M. (2007). Dilemmas of public university reform in Malaysia (Vol. no. 63.). Clayton, Vic: Monash University Press.

Schiller, D., \& Liefner, I. (2006). Higher education funding reform and university-industry links in developing countries: The case of Thailand. from Spinger Science+Business Media B.V. 2006

Serdar, A. M. (2010). Performance management and key performance indicators for higher education institutions in Serbia. Perspectives of Innovations, Economics and Business, 6(3), 120.

Sidhu, G. K., \& Kaur, S. (2011). Enhancing global competence in higher education: Malaysia strategic initiatives. Journal of Higher Education in the Asia-Pacific, 36(4), 219-236. http://dx.doi.org/10.1007/978-94-007-1500-4_11

Sirat, M. (2008a). Review of higher education institutions in regional development: The OECD programme on institutional management in higher education and directorate for public governance and territorial development. Penang, Malaysia.

Strehl, F., Reisinger, \& Kalatschan. (2007a). Funding systems and their effects on higher education system (Vol. No. 6): OECD Education Working Papers.

Tammi, T. (2009). The competitive funding of university research: The case of Finnish science universities. Higher Education, 57(5), 657-679. http://dx.doi.org/10.1007/s10734-008-9169-6

Teixeira, P., \& Koryakina, T. (2011). Funding reforms and revenue diversification - patterns, challenges and rhetoric. Studies in Higher Education(Journal Article), 1-18. http://dx.doi.org/10.1080/03075079.2011.573844

Zhao, F. (2001). Impact of diversification of financing sources on higher education quality. Assessment \& Evaluation in Higher Education, 26(5), 427 - 436. http://dx.doi.org/10.1080/02602930120082005

Table 1. Higher Education Institution in Malaysia

\begin{tabular}{lclc}
\hline Public & Number & Private & Number \\
\hline Public University & 20 & Private University & 8 \\
Polytechnic & 22 & Private University Colleges & 15 \\
Community College & 37 & $\begin{array}{l}\text { Foreign Branch Campus University in } \\
\text { Malaysia }\end{array}$ & 4 \\
Public College & 1 & $\begin{array}{l}\text { Private Colleges (Non-University } \\
\text { status) }\end{array}$ & 488 \\
Teacher Education Intuitions & 27 & Total & 515 \\
Total & 107 & & \\
\hline
\end{tabular}

Source: Ministry of Higher Education (2010) 
Table 2. Performance Indicators Used in Higher Education

\begin{tabular}{|c|c|}
\hline Source & Teaching \\
\hline $\begin{array}{l}\text { Selected performance indicators in } \\
\text { higher education } \\
\text { Cave, Kogan and Hanney (1989) }\end{array}$ & $\begin{array}{l}\text { - } \text { Cost per student or ratio } \\
\text { - Value added } \\
\text { - } \text { Rate of return } \\
\text { - Wastage and non-completion rates } \\
\text { - Employment on graduating or after five years } \\
\text { - Student and peer review }\end{array}$ \\
\hline $\begin{array}{l}\text { Variables for analysing higher } \\
\text { education institutions in Europe. } \\
\text { Bonaccorsi and Daraio (2007) }\end{array}$ & $\begin{array}{ll}\text { - } & \text { Number of undergraduate students } \\
\text { - } & \text { Number of undergraduate degrees } \\
\text { - } & \text { Number of PhD students } \\
\text { Number of PhD degrees }\end{array}$ \\
\hline $\begin{array}{l}\text { Teaching and research indicators in } \\
\text { Australia } \\
\text { Guthrie \& Neumann (2007) and } \\
\text { Neumann \& Guthrie (2006) }\end{array}$ & 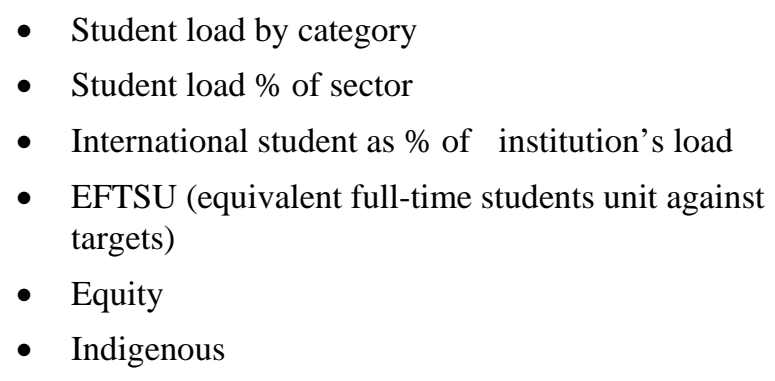 \\
\hline
\end{tabular}

Table 3. Summary of Statistics Used in the Study

\begin{tabular}{ccl}
\hline \multicolumn{2}{c}{ Tests } & Details \\
\cline { 1 - 2 } Parametric & Non-parametric & $\begin{array}{l}\text { One-sample } \\
\text { One-sample t test }\end{array}$ \\
$\begin{array}{c}\text { Wilcoxon signed } \\
\text { rank test }\end{array}$ & $\begin{array}{l}\text { indicates the respondents' agreement that funding changes } \\
\text { on teaching and learning according to the whole public } \\
\text { university sectors. }\end{array}$
\end{tabular}

Table 4. Focus Group Interviews

\begin{tabular}{ll}
\hline University Category & Code \\
\hline Research University & University A \\
& University B \\
Comprehensive University & University C \\
Focused University & University D \\
\hline
\end{tabular}


Table 5. Respondent Demographic Analysis

\begin{tabular}{|c|c|c|}
\hline Demographic Characteristics & Frequency & $\begin{array}{c}\text { Percentage } \\
\text { (\%) }\end{array}$ \\
\hline \multicolumn{3}{|l|}{ University category } \\
\hline Research University (Apex) & 10 & 8.30 \\
\hline Research Universities & 31 & 25.8 \\
\hline Comprehensive Universities & 27 & 22.5 \\
\hline Focused Universities & 52 & 43.3 \\
\hline \multicolumn{3}{|l|}{ Designated position } \\
\hline Vice Chancellor/Rector & 2 & 1.70 \\
\hline Deputy Vice Chancellors/Deputy Rectors & 20 & 16.7 \\
\hline Deans & 81 & 67.5 \\
\hline Heads of Bursar Office or equivalent & 9 & 7.50 \\
\hline Directors of Strategic Planning Office or equivalent & 8 & 6.70 \\
\hline Total & 120 & 100 \\
\hline
\end{tabular}

Table 6. Results of One Sample Wilcoxon Signed Rank Test and One Sample T-test

\begin{tabular}{lccccccc}
\hline \multirow{2}{*}{ Variables } & \multicolumn{2}{c}{$\begin{array}{l}\text { One Sample Wilcoxon } \\
\text { Signed Rank Test }\end{array}$} & \multicolumn{5}{c}{ One Sample T-test } \\
\cline { 2 - 8 } & Sig & Median & Mean & $t$ & Sd & df & Sig \\
\hline $\begin{array}{l}\text { Improved overall quality of } \\
\text { T\&L }\end{array}$ & .000 & 6 & 5.33 & 12.43 & 1.16 & 117 & .000 \\
$\begin{array}{l}\text { Increased number of } \\
\text { undergraduate students }\end{array}$ & .000 & 5 & 4.88 & 7.10 & 1.35 & 119 & .000 \\
$\begin{array}{l}\text { Increased number of } \\
\text { postgraduate students }\end{array}$ & .000 & 6 & 5.58 & 16.06 & 1.07 & 119 & .000 \\
$\begin{array}{l}\text { Increased number of } \\
\text { international students }\end{array}$ & .000 & 5.5 & 5.32 & 13.21 & 1.09 & 119 & .000 \\
$\begin{array}{l}\text { Increased number of } \\
\text { undergraduate degrees } \\
\begin{array}{l}\text { Increased number of } \\
\text { postgraduate degrees }\end{array}\end{array}$ & .000 & 5 & 4.89 & 7.78 & 1.26 & 119 & .000 \\
\hline
\end{tabular}

